\title{
SYSTEMATIC RELATIONS AMONG Philornis MEINERT, Passeromyia RODHAIN \& VILLENEUVE AND ALLIED GENERA (DIPTERA, MUSCIDAE)
}

\author{
COURI, M. S. ${ }^{1,3}$ and CARVALHO, C. J. B..$^{2,3}$ \\ ${ }^{1}$ Departamento de Entomologia, Museu Nacional, Quinta da Boa Vista, CEP 20940-040, Rio de Janeiro, RJ, Brazil \\ ${ }^{2}$ Departamento de Zoologia, Universidade Federal do Paraná, Curitiba, Paraná, CEP 81531-980, Brazil \\ ${ }^{3}$ Research fellow of Conselho Nacional de Desenvolvimento Científico e Tecnológico, CNPq \\ Correspondence to: Márcia S. Couri, Museu Nacional, Quinta da Boa Vista, CEP 20940-040, \\ Rio de Janeiro, RJ, Brazil, e-mail: mcouri@attglobal.net \\ Received Juny 27, 2002 - Accepted August 20, 2002 - Distributed May 31, 2003
}

(With 1 figure)

\begin{abstract}
Passeromyia Rodhain \& Villeneuve and Philornis Meinert are the only known Muscidae whose larvae are parasites of birds. Passeromyia is known from the Old World and Philornis from the New World. Opinions on the relations between these two genera and their systematic positions among the Muscidae have varied. This survey aims to clear the discussion on the relations of Passeromyia, Philornis, and of some allied genera and give an overview of the classification of the Muscidae based on cladistic methodology. Thirty-two terminal taxa ( 2 of them outgroups) were analysed based on 54 characters. The cladistic analysis, carried out using Hennig86, resulted in 1 minimal tree (length 373), with a consistency index of 71 and a retention index of 85. Philornis and Passeromyia belong to a monophyletic group, supported by a synapomorphy, the presence of a cocoon, enclosing the pupa. The phylogenetic relationships found in this group are: (Muscina (Philornis (Phaonina ((Fraserella, Passeromyia) (Synthesiomyia (Calliphoroides, Reinwardtia)))))). Other probable monophyletic muscid groups, like Muscinae (with Stomoxyini and Muscini) and Coenosiinae (with Limnophorini and Coenosiini) are also discussed. Phylogenetic patterns within Reinwardtinae and Dichaetomyiinae could be explained by a Gondwana distribution.
\end{abstract}

Key words: Muscidae, Passeromyia, Philornis, cladistics, biogeography.

\section{RESUMO}

\section{Relações sistemáticas entre Passeromyia Rodhain \& Villeneuve, Philornis Meinert e gêneros relacionados (Diptera, Muscidae)}

Passeromyia Rodhain \& Villeneuve e Philornis Meinert são os únicos gêneros de Muscidae cujas larvas são parasitas de aves. Passeromyia é conhecido do Velho Mundo e Philornis, do Novo Mundo. Opiniões sobre as relações entre esses dois gêneros e suas posições sistemáticas entre os Muscidade têm variado. Este trabalho tem por objetivo esclarecer as relações de Passeromyia, Philornis e de alguns gêneros relacionados com eles e dar uma visão da classificação de Muscidae com base na metodologia cladística. Foram analisados 32 táxons terminais ( 2 deles como grupos externos), com base em 54 caracteres. Na análise cladística foi utilizada o Hennig86. A análise resultou em uma árvore de menor comprimento (373), com índice de consistência 71 e índice de retenção 85. Philornis e Passeromyia pertencem ao mesmo grupo monofilético, suportado por uma sinapomorfia - presença de um casulo envolvendo a pupa. As relações filogenéticas encontradas neste grupo são: (Muscina (Philornis (Phaonina ((Fraserella, Passeromyia) (Synthesiomyia (Calliphoroides, Reinwardtia)))))). Outros prováveis grupos monofiléticos de muscídeos, como Muscinae (com Stomoxyini e Muscini) e Coenosiinae (com Limnophorini e Coenosiini), também são discutidos. Os padrões filogenéticos dentro de Reinwardtinae e Dichaetomyiinae podem ser explicados por uma distribuição Gondwana.

Palavras-chave: Muscidae, Passeromyia, Philornis, cladística, biogeografia. 


\section{INTRODUCTION}

Passeromyia Rodhain \& Villeneuve and Philornis Meinert are two of the most interesting muscid genera, found in larvae. Biology present knowledge shows that the larvae are parasites of birds, associating with then in ways ranging from scavenging in their nests to subcutaneous bloodfeeding. Pont (1974) revised Passeromyia and provided data on the biology of the species. Couri (1999) and Teixeira (1999) summarized the available data on Philornis relations with birds. Carvalho \& Couri (2002a) presented a key to species, modified from Couri (1999).

Passeromyia is distributed throughout the Old World, Afrotropical and Oriental regions, Australasia, and the Western Pacific (Pont, 1974) and Philornis is known from the New World, mainly in the Neotropical region, with 2 species occurring in the southern United States. Besides larval behaviour similarities, both genera also share some morphological characters like the presence of a tuft of bristles on the post-alar wall (present in all Philornis species and in some Passeromyia) and very similar ovipositor morphology.

Opinions on the systematic position of both genera among the Muscidae have varied, especially regarding Passeromyia, for which Pont (1974) presented those of many authors. Malloch (1925, 1928), Séguy (1937), Hardy (1937), and Emden (1939) placed the genus among the Muscinae, based on the upward curvature of vein $\mathrm{M}$ and the truncated lower squama. Townsend $(1935,1937)$ considered Passeromyia in the tribe Hemichlorini, together with Ornithomusca Townsend, Hemichlora Wulp, Ochromusca Malloch, and Synthesiomyia Brauer \& Bergenstamm. Emden (1965) and Hennig (1965) considered Passeromyia close to other Old World genera such as Muscina Robineau-Desvoidy, Synthesiomyia Brauer \& Bergenstamm, Calliphoroides Malloch, Fraserella Steyskal, Phaonina Emden, and Phaonidia Emden. Emden (op. cit.) included these genera in the Phaoniini, Phaoniinae, while Hennig (op. cit.) included them in the Muscinae (tribe Hydrotaeini), a subfamily he considered paraphyletic. Vockeroth (1972) included the genus in the Muscinae: "Whilst the male aedeagus places the genus in Hennig's group Muscinae + Phaoniinae, the female ovipositor supports assignment in the Muscinae whilst the absence of proclinate ors on the female frons indicates the Phaoniinae". Pont (op. cit.) also mentioned the similarity between Passeromyia and Philornis (= Neomusca Malloch), which differ chiefly by the presence of hairs on the anepimeron of all Philornis species. Pont (1972) placed Philornis in the subfamily Cyrtoneurininae which according to him (Pont, 1974), is a paraphyletic group.

More recent publications and catalogues also show divergence on the Passeromyia systematic position. Pont (1980, 1989) placed the genus among the Muscinae, tribe Hydrotaeini and Reinwardtiini, respectively.

In the Skidmore (1985) classification, Passeromyia and Philornis are placed in the tribe Reinwardtiini, subfamily Reinwardtiinae, together with Ochromusca, Alluaudinella Giglio-Tos, Aethiopomyia Malloch, Charadrella Wulp, Muscina Robineau-Desvoidy, Synthesiomyia, and Calliphoroides. He also mentioned that the close parallels between Passeromyia and Philornis in larval morphology also suggest that they may be closely related.

Carvalho (1989) in his classification of the family Muscidae based on cladistic analysis, placed Philornis among the Reinwardtiini, tribe of Azeliinae, together with Dalcyella Carvalho, Reinwardtia Brauer \& Bergenstamm, Brachygasterina Macquart, Palpibracus Rondani, and Psilochaeta Stein. Carvalho et al. (1993) and Carvalho \& Couri (2002a) followed this classification, placing Philornis among the Reinwardtiini, subfamily Azeliinae. None of these papers included the genus Passeromyia in their studies.

Passeromyia is known from 5 described species: P. heterochaeta (Villeneuve), P. indecora (Walker), P. steini Pont, P. longicornis (Macquart), and $P$. veitchi Bezzi. The larvae of these species are known to be scavengers in bird nests (P. steini); external parasites of nestlings, remaining on the body surface and piercing the skin to suck blood $(P$. heterochaeta); or subcutaneous parasites of the nestlings ( $P$. indecora). In the last case, if the host dies the subcutaneous larvae can feed on the carcass until ready to pupate (Pont, 1974). The life history of $P$. longicornis and $P$. veitchi is unknown.

Philornis is a bigger genus, known from 50 species (Dodge, 1955; Carvalho et al., 1993), the majority of them described in the sixties by Dodge (1963, 1968) and Dodge \& Aitken (1968) and in the eighties by Couri $(1983,1984)$. The same range of larval habits found in Passeromyia, is also found in Philornis: free-living larvae in bird nests, with coprophagous habits ( $P$. aitkeni Dodge and $P$. rufoscutellaris Couri); free-living in nests, semi- 
hematophagous ( $P$. downsi and P. falsifica); and subcutaneous bloodfeeders (the majority of the species, with known larval biology).

The main objectives of this paper are to clarify the relations of Passeromyia and Philornis and the discussion on the evolutionary line of larvae habits (see also Dodge, 1971) based on cladistic methodology.

\section{MATERIAL AND METHODS}

The material used in this study belongs to Museu Nacional, Rio de Janeiro, Brazil; The Natural History Museum, London; Canadian National Collection of Insects, Ottawa; and the Australian National Insect Collection, Canberra.

The terminal taxa are represented by Philornis, Passeromyia and the following related genera considered by different authors as in different positions among the Muscidae, but close to those two: Aethiopomyia, Alluaudinella, Calliphoroides, Charadrella, Fraserella, Muscina, Ochromusca, Phaonina, Reinwardtia, and Synthesiomyia.

Besides these, other muscid genera were added to the analysis: Coenosia Meigen; Cyrtoneurina GiglioTos; Cyrtoneuropsis Malloch [= Paracyrtoneurina Pamplona (Pamplona, 1999; Pont \& Pamplona, 2000)]; Dichaetomyia Malloch; Dolicophaonia Carvalho; Hydrotaea Robineau-Desvoidy; Limnophora Robineau-Desvoidy; Micropotamia Carvalho; Mydaea Robineau-Desvoidy; Morellia Robineau-Desvoidy; Musca Linnaeus; Neodexiopsis Malloch; Polietina Schnabl \& Dziedzicki; Scutellomusca Townsend; Souzalopesmyia Albuquerque; and Stomoxys Geoffroy. Each genus is represented by one species, except for Philornis and Passeromyia, represented by two species, one with coprophagous and the other with hematophagous larvae. The scanty information on Phaonidia Emden, also referred to by some authors as being close to Passeromyia, made it impossible to consider this genus in the analysis.

The cladistic analysis was carried out using Hennig86, version 1.5 (Farris, 1988), running in "Tree Gardener", version 2.2 (Ramos, 1997), a program designed for running Hennig86 in a Windows environment. Minimum-length trees were calculated using the options "mhennig" associated with "successive weighting".

Thirty-two terminal taxa were analyzed based on 54 characters. Characters were polarized by the outgroup method (Watrous \& Wheeler, 1981; Maddison et al., 1984). The outgroups were represented by two Anthomyiidae genera: Coenosopia Malloch and Phaonantho Albuquerque. These two genera are the only ones among the Anthomyiidae where the anal vein does not reach the wing margin (as found in Muscidae). Michelsen (1991) proposed Anthomyiidae as the sister-group of the Muscidae.

Characters were coded as binary and multistate. The latter was considered as additive or non-additive, depending on available information on the contiguity of states in the outgroups. Information not available was coded as a question mark (?). The character distributions were examined using Tree Gardener and Clados (Nixon, 1995).

Table 1 shows the matrix and the characters used in the analysis.

\section{RESULTS AND DISCUSSION}

The cladistic analysis resulted in 1 minimal length (373) tree, with a consistency index of 71 and retention index of 85 (Fig. 1). The monophyly of the Muscidae was confirmed by the loss of the postabdominal spiracles in the female, as pointed out by Hennig $(1965,1973)$. Among the Muscidae, only Acanthiptera Rondani and Cariocamyia Snyder have independently re-acquired spiracle 6 (Carvalho \& Couri, 2002a).

The classification shows that Philornis and Passeromyia belong to a monophyletic group supported by one synapomorphy, the presence of a cocoon, enclosing the pupa. This clade includes the following genera: Muscina, Philornis, Phaonina, Fraserella, Passeromyia, Synthesiomyia, Calliphoroides, and Reinwardtia.

Skidmore (1985) placed Philornis close to Passeromyia because, according to him, "it appears inconceivable that many similarities between these two genera should be due merely to convergence. The same range of larval habits is found in both genera, but elsewhere in the Muscidae parasitism of birds is known except in Muscina and Synthesiomyia where it is of purely casual nature". The present analysis shows this character (larvae associated with birds) as having appeared independently in both genera.

Muscina also has different positions among the Muscidae, according to different authors: Phaoniinae (Collin, 1948), Muscinae (Hennig, 1965). According to Skidmore (op. cit.) there can be no doubt about the close affinity between Muscina, Synthesiomyia, and Passeromyia. 


\section{TABLE 1}

Data matrix and characters of some Muscidae genera used in the analysis. $0=$ plesiomorphic character states; 1 and 2 = apomorphic character states; ? = missing data.

\begin{tabular}{|ll|}
\hline Phaonantho & $00000000000000000000000000000001000000000000000000 ? ? 00$ \\
Coenosopsia & $02000000000001000000000000010100000000000000000000 ? 00$ \\
Alluaudinella & $011001 ? 00 ? 1000001001 ? 001110 ? 01110000000000100000110010$ \\
Aethiopomyia & $011001 ? 00 ? 1000001001 ? 001110 ? 011101000 ? ? ? ? ? ? ? ? ? ? ? 1 ? ? 0 ? 1$ \\
Calliphoroides & $101011010100001000000011010111110010000000010000100 ? 1 ?$ \\
Charadrella & 021011100000001010010001100101110020000000100010110011 \\
Coenosia & 021101010100110100100000002101110001100100010001101010 \\
Cyrtoneurina & 001001000000000010011010110101110000000000010000100010 \\
Cyrtoneuropsis & 001000000000000010010010110101110000000000110000100011 \\
Dichaetomyia & $00100100010000001001101010010111000000000010000010 ? 010$ \\
Dolichophaonia & $011001000100000000000000000001010000100000010000100 ? 10$ \\
Hydrotaea & 010000020100000000000000011101000000001000010000101010 \\
Fraserella & $0 ? 1011000 ? 0100 ? 0000000 ? 1010 ? 010100100 ? ? ? ? ? ? ? ? ? ? ? 10 ? ? ? ?$ \\
Limnophora & 001101010100110110000000000101110101100111100111101020 \\
Micropotamia & 000001010100000001000000001001000000101000010000101010 \\
Morellia & 100000000100000000010001110011011010010000021000100000 \\
Musca & 010011000100000010010001110001010010010000021000100000 \\
Muscina & 011011000100000001000010010101010000000000010000101110 \\
Mydaea & 001001000100000000000000110101110100100011100111101020 \\
Neodexiopsis & 021101010100110100100000002101110001100100010001101010 \\
Ochromusca & $011001100 ? ? 000 ? 010011001100 ? 011101100 ? ? ? ? ? ? ? ? ? ? ? 110010$ \\
Passeromyia steini & 021010101101001000000011010101010010000000010000120110 \\
Passeromyia heterochaeta 021010101101001000000111010101010010000000010000122110 \\
Phaonina & $0110 ? ? 000 ? 000010000000 ? 1 ? 10 ? 010100000 ? ? ? ? ? ? ? ? ? ? ? 1 ? ? ? ? ?$ \\
Philornis aitkeni & 001011000100000000011111110101110020000000010000120110 \\
Philornis trinitensis & 011011000100000000011111110101110020000000010000122110 \\
Polietina & 000000000100000010011100010001011000010000011000100011 \\
Reinwardtia & $1 ? 10110201010010000000111001111100100000000100001 ? 0 ? 1 ?$ \\
Scutellomusca & 001001000100000000000010110101110110000011100111101020 \\
Souzalopesmyia & $011001100100000000001000100001110000100000010000100 ? 10$ \\
Stomoxys & $010001000100 ? 000100100011 ? 3 ? 01111000000000110000100000$ \\
Synthesiomyia & 011011020100001011000011010101010010000000010000101110 \\
\hline
\end{tabular}

General body coloration: (0) nonmetallic (1) metallic [ci: 50; ri: 50; weight: 2; steps: 2]

1. Distance of frons at narrowest part in male: (0) holoptic (not greater than anterior ocelli diameter) (1) intermediate (until 0.1 of head width) (2) intermediate (more than 0.1) (3) dichoptic (distance as in female) [ci: 16; ri: 37; weight: 0; steps: 12]

2. Ors proclinate in female: (0) present (1) absent [ci: 100; ri: 100; weight: 10; steps: 1]

3. Number of frontal pairs of bristles: (0) until 4 (1) more than 5 [ci: 100; ri: 100; weight: 10; steps: 1]

4. Cilia on parafrontal plate: (0) parafacialia almost naked; (1) numerous cilia 5 [ci: 33; ri: 80; weight: 2 ; steps: 3]

5. Interfrontal cruciate bristles in female: (0) present (1) absent [ci: 16; ri: 28; weight: 0; steps: 6]

6. Length of flagellomere compared with pedicel: $(0)$ until 3 times longer (1) more than 3 times longer [ci: 33; ri: 50; weight: 1 ; steps: 3 ]

7. Length of plumae at arista: (0) long (1) short (2) almost naked [ci: 40; ri: 50; weight: 2; steps: 5]

8. Dorsal and ventral plumes at arista: (0) similar (1) dorsal plumes longer and sparser than ventral ones [ci: 100; ri: 100; weight: 10; steps: 1

9. Secondary cilia/plumes at arista: (0) absent (1) present [ci: 50; ri: 75; weight: 3 ; steps: 2] 


\section{TABLE 1 (Continued.)}

10. Secondary cilia/plumes at arista: (0) absent (1) present [ci: 50; ri: 75; weight: 3 ; steps: 2 ]

11. Remarkably short stubby spines on the upper side of the palpi [ci: 100; ri: 100; weight: 10; steps: 1]

12. Cilia at ey es: (0) absent or very short (1) numerous [ci: 50; ri: 66; weight: 3 ; steps: 2]

13. Shape of labellum: (0) not reduced (1) reduced [ci: 100; ri: 100; weight: 10; steps: 1]

14. Prestomal teeth: (0) absent (1) present [ci: 50; ri: 66; weight: 3 ; steps: 2 ]

15. Cilia at facial ridge: (0) absent (1) present [ci: 50; ri: 83; weight: 4; steps: 2]

16. Prealar seta: (0) present (1) absent [ci: 100; ri: 100; weight: 10; steps: 1]

17. Cilia at prosternum (0) absent (1) present [ci: 20; ri: 63; weight: 1 ; steps: 5]

18. Color of prosternum: (0) not glossy (1) glossy [ci: 33; ri: 0; weight: 0 ; steps: 3 ]

19. Lower proepimeral seta: (0) upcurved (1) downcurved [ci: 100; ri: 100; weight: 10; steps: 1]

20. Cilia at anepimeron: (0) absent (1) present [ci: 33; ri: 83; weight: 2 ; steps: 3 ]

21. Setae at margins of posterior spiracle: (0) absent (1) present [ci: 16; ri: 16; weight: 0; steps: 6]

22. Setae at post-alar declivity: (0) absent (1) present as a tuft [ci: 33; ri: 33; weight: 1 ; steps: 3]

23. Setulae on lateral margins of scutellum: (0) absent (1) present [ci: 33; ri: 81 ; weight: 2 ; steps: 3 ]

24. Len gth of inferior caly pter related to the superior one: (0) at most twice as long as (1) enlarged, more than three times [ci: 25; ri: 80; weight: 2 ; steps: 4]

25. Acrostichal post-sutural setae: (0) differentiated (1) not differentiated [ci: 14; ri: 57; weight: 0 ; steps: 7]

26. Number of dorso-central post-sutural setae: (0) 3 (1) 4 [ci: 12; ri: 36; weight: 0 ; steps: 8 ]

27. Arrangement of katepisternals: (0) 1:2 (1) 1:1 (2) 1:1:1 (3) 0:1 [ci: 100; ri: 100; weight: 10; steps: 3 ]

28. Len gth of anterior katepisternal related to posterior one: (0) almost as long as (1) shorter [ci: 33; ri: 66; weight: 2; steps: 3 ]

29. Inferior caly per darker and with hairs: (0) absent (1) present [ci: 50; ri: 50; weight: 2; steps: 2]

30. Cilia on inferior portion of scutellum: (0) present (1) absent [ci: 100; ri: 100; weight: 10; steps: 1]

31. Calcar: (0) present long (1) present short (2) absent [ci: 20; ri: 69; weight: 1; steps: 5]

32. Subcostal vein: (0) smooth (1) sinuose [ci: 50; ri: 50; weight: 2 ; step s: 2 ]

33. Cilia on apical dorsal section of stem vein (0) absent (1) present [ci: 50; ri: 50; weight: 2; steps: 2]

34. Cilia at both surfaces of R4+5: (0) absent (1) present [ci: 33; ri: 50; weight: 1; steps: 3]

35. Course of M 1+2 at end: (0) nearly straight or very weakly bowed upwards (1) strongly bowed upwards (2) divergent [ci: 33 ; ri: 63 ; weight: 2 ; steps: 6 ]

36. Length of anal vein: (0) long (1) short [ci: 100; ri: 100; weight: 10; steps: 1]

37. Cilia at sternite 1: (0) present (1) absent [ci: 33; ri: 66; weight: 2 ; steps: 3 ]

38. Spined process on ventral surface of cercal plate (0) absent (1) present [ci: 100; ri: 100; weight: 10; steps: 1]

39. Small spinules on juxta on male distiphallus: (0) absent (1) present [ci: 100; ri: 100; weight: 10; step s: 1]

40. Shape of male hy pandrium: (0) plate-like (1) tubular [ci: 100; ri: 100; weight: 10; steps: 1]

41. Shape of female hy poproct: (0) not modified, with setae (1) elon gated and with spines [ci: 50; ri: 50; weight: 2 ; steps: 2$]$

42. Ovipositor: (0) straight (1) curve [ci: 50; ri: 50; weight: 2 ; steps: 2]

43. Ovipositor: (0) long (1) medium [ci: 25 ; ri: 57 ; weight: 1 ; steps: 4 ]

44. Shape of the tergites: (0) large (1) fine to medium (2) anchor-type [ci: 40; ri: 62 ; weight: 2 ; steps: 5]

45. Bristles on sternite 8: (0) not strong (1) strong [ci: 100; ri: 100; weight: 10; steps: 1 ]

46. Spicules at membranae of the segment 8 of the ovipositor: (0) absent (1) present [ci: 50; ri: 50; weight: 2; steps: 2]

47. Len gth of cerci at ovipositor: (0) long (1) short (not surpassing hypoproct) [ci: 33; ri: 33; weight: 1; steps: 3]

48. Setae at cerci: (0) on both surfaces (1) only on external surafce [ci: 100; ri: 100; weight: 10; steps: 1]

49. Spiracle 6 of the ovipositor: (0) present (1) absent [ci: 100; ri: 100; weight: 10; steps: 1$]$

50. Larval habits: (0) not parasite (1) parasite, associated with snails (2) parasite, associated with birds [ci: 66; ri: 80; weight: 5 ; steps: 3$]$

51. Larval feeding habitus: (0) saprophagous/coprophagous (1) carnivorous (2) hematophagous [ci: 33; ri: 55; weight: 1 ; steps: 6 ]

52. Cocoon: (0) absent (1) present [ci: 100; ri: 100; weight: 10; steps: 1]

53. Egg type: (0) Musca (1) Phaonia (2) Mydaea [ci: 50; ri: 66; weight: 3; steps: 4]

54. Viviparity: (0) does not occur (1) occurs [ci: 25; ri: 0; weight: 0; steps: 4] 


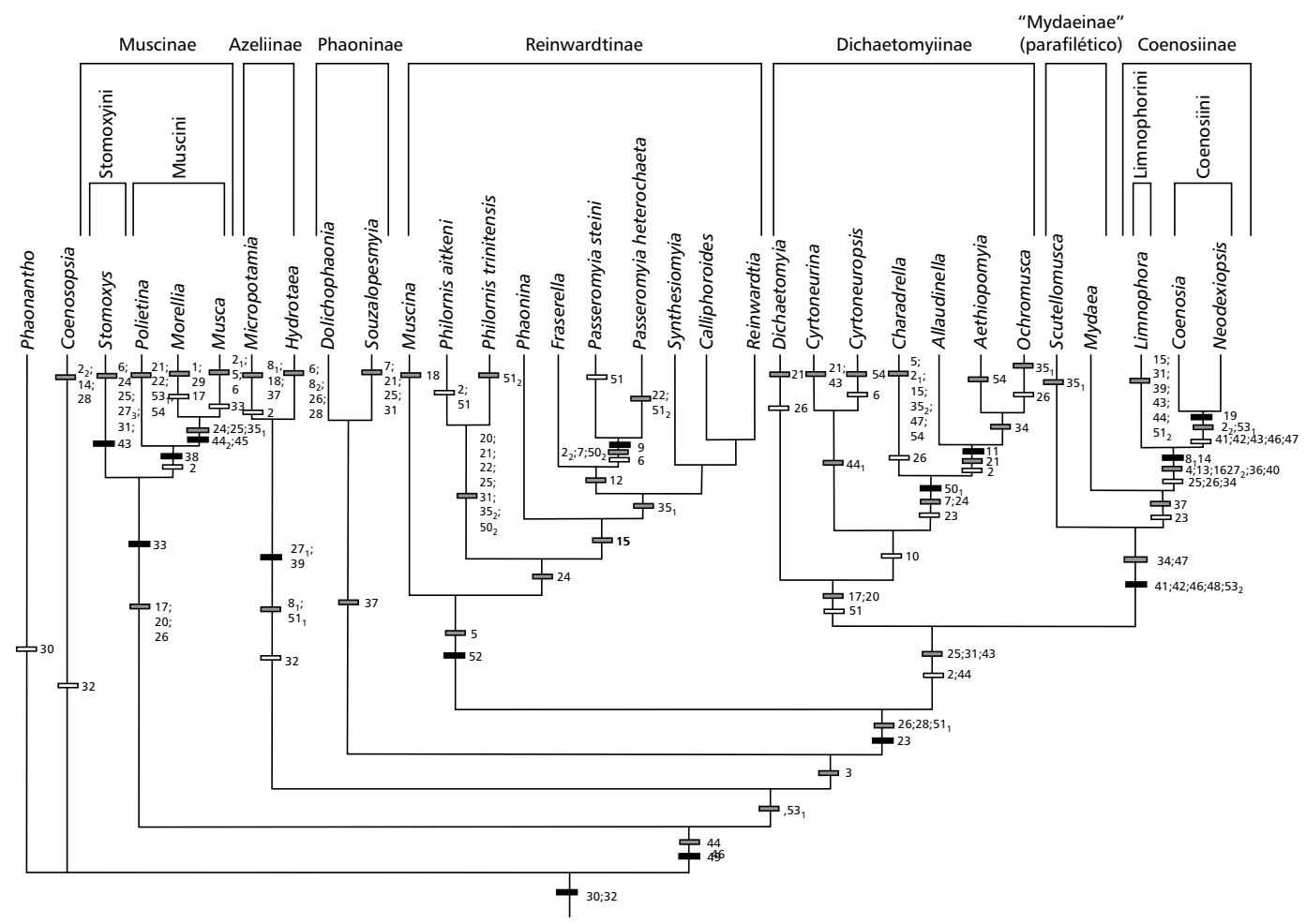

Fig. 1 - Cladogram depicting the phylogenetic relationships among the species of some Muscidae genera. Length: 373; ci: 71; ri: 85. Black boxes, synapomorphies; stippled boxes, homoplasies; clear boxes, reversals.

Unfortunately little information was available on Phaonina and Fraserella. Phaonina, according to Skidmore (1985) "has many unusual features which render its true affinities uncertain". He placed this genus among the "aberrant Reinwardtinae" and in the tribe Hemichlorini, together with Cyrtoneurina, Neomuscina Townsend, Polietina Schnabl \& Dziedzicki, and Metopomyia Malloch. In the present analysis they appear closely related to Passeromyia in a monophiletic group also formed by Synthesiomyia, Calliphoroides, and Reinwardtia.

The close relations between Calliphoroides and Reinwardtia, corroborated in this analysis, were long discussed by Hennig (1965) who placed them among the Muscinae. The strong curvature at the end of the vein $\mathrm{M}$, used by many authors to characterize this subfamily, was a homoplasic character state in this analysis. Hennig (op. cit.) also approximated Calliphoroides to Muscina and Synthesiomyia.
In this analysis, Alluaudinella, Aethiopomyia, and Ocrhomusca appear to form a monophyletic group, defined by the presence of remarkably short stubby spines on the upper side of the palpi. Pont (1980) following Hennig (1965) considered Ocrhomusca, Aethiopomyia, and Alluaudinella in the Dichaetomyiini. Emden (1939) placed them in the Muscinae based on their Musca-type thoracic calypter. Skidmore (1985) mentioned that the larval mouthparts and larval spiracle of Ocrhomusca suggest a close relationship with Muscina and Synthesiomyia. According to Skidmore (op. cit.) these three genera are clearly closely related. The larva of Ocrhomusca and Alluaudinella feed on dead snails and, although the larval habits of Aethiopomyia are not known, the final larval instar of Aethiopomyia closely resemble those of Ochromusca, Alluaudinella, Synthesiomyia, and Muscina (Skidmore, 1985). 
Charadrella appears as the sister group of (Alluaudinella (Aethiopomyia, Ocrhomusca)) forming with them a monophyletic group based on the association of their larvae with snails. Skidmore (1985) considered that, although it shares with the three previously mentioned genera an unusual mode of life and some structural affinity, it may not be particularly closely related to them nor to Muscina and Synthesiomyia. Skidmore (op. cit.) provisionally placed Charadrella close to Ocrhomusca on the strength of their biology. A more complete analysis will certainly better define this relation. Charadrella together with the three preceding genera were considered to be in Reinwardtiini (Reinwardtinae) by Skidmore (op. cit.).

Cyrtoneurina and Cyrtoneuropsis appeared close to these groups of genera. Skidmore (1985) examined Cyrtoneuropsis gemina Wiedemann in his study, considering it as a Hemichlrorini (Reinwardtiinae). He mentioned that the species is apparently "archaic combining some features of the Reinwardtinae, Muscinae and Azeliinae”.

The paleotropical genus Dichaetomyia (two species in the Palearctic, Skidmore, 1985), seems closely related to this group in the analysis. According to Skidmore (1985) Dichaetomyia appears to be closely related to Phaonia, "but further work may reveal that some of the species included under this genus belong to the Ochromusca group".

Although using few genera representing the other muscid subfamilies, the resulted cladogram corroborated the data in the literature, showing some monophyletic muscid groups such as Muscinae. This subfamily appears in the base of the cladogram and is here represented by Stomoxys, Polietina, Morellia, and Musca. The "Azeliini” (as termed by Carvalho, 1993) was represented by Micropotamia and Hydrotaea. The genus Micropotamyia was constructed by Carvalho (1993) who also presented a discussion of some character-states of phylogenetic importance to Azeliini (as termed by Carvalho, 1989), a tribe in which Micropotamyia was included. Carvalho (op. cit.) called attention to the striking configuration of the male distiphallus, with juxta spinulose, shared by the Azeliini genera. He also mentioned that although there is no published phylogenetic hypothesis for intergeneric relationships in Azeliini, there is evidence that the tribe is monophyletic (Michelsen, 1978; Carvalho, 1993).

The other monophyletic group, and one of the most solidly based among the Muscidae - Mydaeinae +
Coenosiinae (Hennig, 1965; Carvalho, 1989; Couri $\&$ Pont, 2000) appears at the apex of the cladogram supported by five sinapomorphies. Scutellomusca and Mydaea, considered today among the Mydaeinae, did not form a monophyletic group. The Coenosiinae represented by Limnophora, Coenosia, and Neodexiopsis confirmed their monophyly (six sinapomorphies). The last two genera, known as well as the tribe Coenosiini, also confirmed their monophyly, supported by one sinapomorphy (see also Couri, 2000).

\section{BIOGEOGRAPHICAL ANALYSIS}

Historical biogeographical studies on the Muscidae family are few, and rare are the hypotheses about the distribution patterns of the muscid species. In the sixties, Hennig (1965) explained such patterns of some muscid species based exclusively on dispersion. Carvalho (1999) and Carvalho \& Couri (2002b) analyzed distribution patterns of muscid species using vicariance, but both studies were based on genera occurring exclusively in the Neotropical region. Although Hennig (1965) theorized on this subject, nothing is actually known about the transoceanic patterns of relationships of muscid species. On the other hand, the intercontinental relationships of the basic groups of Diptera are well known (for a summary, see Amorim \& Tozoni, 1994). At the same time, few papers exist on Schizophora (Griffiths, 1972; Papavero, 1977; Matthis, 1977, 1978; Barnes, 1981; Cortéz, 1983).

Using the methodology of cladistic biogeography, by replacing the taxa nomenclature with names of areas where the species occur, a biological area cladogram can be generated (for methodological procedures, see Morrone \& Crisci, 1995). Based on this, sister group relationships of some genera could be analyzed based on vicariance biogeography.

The distribution pattern of the species among the genera of Reinwarditiinae (Fig. 1) resembles a Gondwana pattern, suggesting that the ancestor of these genera could have appeared before the Upper Cretaceous, the hypothetical age previous to Muscidae (Hennig, 1965). As pointed out in this paper, the breakup of the Gondwana could have strongly affected the pattern distribution of these genera, suggesting an older age for this family.

Pont \& Carvalho (1997) described the first muscids, found in Dominician ambar (about 15-20 
million years ago, the minimum age of those species). Evenhuis (1994) identified a muscid fossil from the Eocene, and Grimaldi \& Cumming (1999) recorded the oldest definitive cyclorrhaphan larvae in Cretaceous ambar, but did not position them in a family (uncertain family).

On the other hand, the distribution pattern here shown for another monophyletic group within the Dichaetomyiinae subfamily formed by Charadrella + Alluaudinella + Aethiopomyia + Ochromusca (Fig. 1) (the first, an exclusively Neotropical genus and the three others Afrotropical) also corroborates a hypothetical older age for the Muscidae.

This older age for Muscidae, as here suggested, is hypothesized to be based on a partial phylogenetic analysis of this family, although some of the resulting monophyletic groups inside this family corroborated previous classifications. Therefore, the hypothetical age of this family remains undefined and more fossil evidence and historic biogeographic studies are required. The geographical distribution of the genera included in this analysis is shown in Table 2.

TABLE 2

Geographical distribution of the analyzed genera.

\begin{tabular}{|c|c|}
\hline Genus name & Geographical distribution \\
\hline Phaonantho & Neotropical \\
\hline Coenosopsia & Nearctic, Neotropical \\
\hline Alluaudinella & Afrotropical \\
\hline Aethiopomyia & Afrotropical \\
\hline Calliphoroides & Australasian \\
\hline Charadrella & Neotropical \\
\hline Coenosia & Cosmopolitan \\
\hline Cyrtoneurina & Neotropical \\
\hline Cyrtoneuropsis & Neotropical \\
\hline Dichaetomyia & Essentially Afrotropica, Oriental, Australasian \\
\hline Dolichophaonia & Essentially Neotropical \\
\hline Hydrotaea & Cosmopolitan \\
\hline Fraserella & Oriental \\
\hline Limnophora & Cosmopolitan \\
\hline Micropotamia & Afrotropical \\
\hline Morellia & Cosmopolitan \\
\hline Musca & Cosmopolitan \\
\hline Muscina & Holarctic (predominantly), Nearctic, Neotropical \\
\hline Mydaea & Cosmopolitan \\
\hline Neodexiopsis & Nearctic, Neotropical \\
\hline Ochromusca & Afrotropical \\
\hline Passeromyia & Mainly tropical-South Africa to east Asia, eastwards to Australia and the West Pacific \\
\hline Phaonina & Oriental-Australasian \\
\hline Philornis & Essentially Neotropical \\
\hline Polietina & Neotropical \\
\hline Reinwardtia & Neotropical \\
\hline Scutellomusca & Neotropical \\
\hline Souzalopesmyia & Neotropical \\
\hline Stomoxys & Cosmopolitan \\
\hline Synthesiomyia & Tropicopolitan \\
\hline
\end{tabular}


Acknowledgments - The authors are most grateful to Drs. Peter Cranston, Jeffrey Cumming, and John Chainey, respectively of the Australian National Collection, the Canadian National Collection, and The Natural History Museum of Brazil for the loan of Passeromyia species and to Dr. Adrian Pont (Oxford University Museum) for suggestions on the manuscript. We are grateful to the Conselho Nacional de Desenvolvimento Científico e Tecnológico, $\mathrm{CNPq}$, for a grant to MSC (process number 300386/80-0) and CJBC (process number 300043/86-4). MSC is also grateful to FAPERJ (proc. E-26/170.627/2001) for financially supporting her project. We also thank the anonymous referee for careful review and suggestions.

\section{REFERENCES}

AMORIM, D. de O. \& TOZONI, S. H. S., 1994, Phylogenetic and biogeographic analysis of the Anisopodoidea (Diptera Bibionomorpha), with an area cladogram for intercontinental relationships. Revta. Bras. Ent., 38: 517-543.

BARNES, J. K., 1981, Revision on the Helosciomyzinae (Diptera). J. R. Soc. N. Z., 11: 45-72.

CARVAlHO, C. J. C., 1989, Classificação de Muscidae (Diptera): uma proposta através da análise cladística. Revta. Bras. Zool., 6: 627-648.

CARVALHO, C. J. B., 1993, Micropotamia, gen. n. of neotropical Muscidae (Diptera, Azeliinae), with comments on allied Azeliini genera. Revta. Bras. Zool., 9(1992): 241-246.

CARVALHO, C. J. B., 1999, Revision, cladistics and biogeography of the neotropical Genus Souzalopesmyia Albuquerque (Diptera: Muscidae). Proc. Entomol. Soc. Wash., 101: 123-137.

CARVALHO, C. J. B. \& COURI, M. S., 2002a, Part I. Basal Groups, pp. 17-132. In: C. J. B. Carvalho (ed.), Muscidae (Diptera) of the neotropical region: taxonomy. Editora Universidade Federal do Paraná, Curitiba, 287p.

CARVALHO, C. J. B. \& COURI, M. S., 2002b, A cladistic and biogeographic analysis of Apsil Malloch and Reynoldsia Malloch (Diptera, Muscidae) of southern South America. Proc. Ent. Soc. Wash., 104: 309-317.

CARVALHO, C. J. B., COURI, M. S., PONT, A. C., PAMPLONA D. \& LOPES, S. M., 1993, Part II. Muscidae, 201p. In: C. J B. Carvalho (ed.), A catalogue of the Fanniidae and Muscidae (Diptera) of the neotropical region. Sociedade Brasileira de Entomologia, São Paulo, 201p.

COLLIN, J. E., 1948, On the classification of the genera allied to Musca L. (Dipt.). Proc. Royal. Ent. Soc. London, 17: 125-127.

CORTÉS, R., 1983, First record of transantarctic relationships in the Tachinidae (Diptera, Muscoidea, Calyptratae). Revta. Bras. Zool., 1: 419-420.

COURI, M. S., 1983, Descrição de seis espécies novas de Philornis Meinert, 1890 (Diptera, Muscidae, Cyrtoneurininae). Revta. Bras. Zool., 43: 297-309.

COURI, M. S., 1984, Notes and descriptions of Philornis flies (Diptera, Muscidae, Cyrtoneurininae). Revta. Bras. Ent., 28: 473-490.
COURI, M. S., 1999, Myiasis caused by obligatory parasites. Ia. Philornis Meinert (Muscidae), pp. 51-70 In: J. H. Guimarães \& N. Papavero (eds.), Myiasis in man and animals in the Neotropical Region. Bibliographic database. Editora Pleaide, FAPESP, São Paulo, 308p.

COURI, M. S., 2000, A new species of Philornis Meinert from Galapagos Islands. Bol. Mus. Nac., Rio de J. (Zoologia), 414: 1-16.

COURI, M. S. \& PONT, A. C., 2000, A cladistic analysis on Coenosiinae (Diptera, Muscidae). Syst. Ent., 25: 373-392.

DODGE, H. R., 1955, New Muscid flies from Florida and the West Indies (Diptera, Muscidae). Florida Entomologist, 38 : 147-151

DODGE, H. R., 1963, A new Philornis with coprophagous larva, and some related species (Diptera, Muscidae). Journal Kansas Ent. Soc., 36: 239-247.

DODGE, H. R., 1968, Some new and little-known species of Philornis (Diptera, Muscidae). Journal Kansas Ent. Soc., 41: $155-164$

DODGE, H. R., 1971, Revisional studies of flies of the genus Philornis (Diptera, Muscidae). Studia Ent., 14: 458-459.

DODGE, H. R. \& AITKEN, T. H. G., 1968, Philornis flies from Trinidad (Diptera, Musidae). Journal Kansas Ent. Soc., 41: 134-154.

EMDEN, F. I. Van., 1939, Muscidae, A: Muscinae and Stomoxydinae. Ruwenzori Expedition. 1934-5. British Museum (Natural History), London, v. 2, pp. 49-89.

EMDEN, F. I. Van, 1965, Diptera 7, Muscidae, Part I. The fauna of India and the adjacent countries. Government of India, Delhi, xiv $+647 p$.

EVENHUIS, N. L., 1994, Catalogue of the fossil flies of the world (Insect: Diptera). Backhuys, Leiden, 600p.

FARRIS, J. S., 1988, Hennig 86, version 1.5. Published by the author, Port Jefferson, New York, 18p.

GRIFFITHS, G. C. D., 1972, The phylogenetic classification of Diptera Cyclorrhapha. In: Dr. W. Junk N.V. (ed.), The Hague, 340p. (Series Entomologica, vol. 8).

GRIMALDI, D. \& CUMMING, J., 1999, Brachyceran Diptera in Cretaceous ambers and Mesozoic diversification of the Eremoneura. Bull. Amer. Mus. Nat. Hist., 239: 124.

HARDY, G. H., 1937, Notes on Australian Muscoidea, II Subfamily Muscinae. Proc. R. Soc. Qd., 48: 22-29.

HENNIG, W., 1965, Vorarbeiten zu einem phylogenetischen System der Muscidae (Diptera, Cyclorrhapha). Stuttg. Beitr. Naturkd., 141: 100 .

HENNIG, W., 1973, Diptera. In: W. Kukenthal (ed.), Handbuck der Zoologie, IV: Arthropoda de Gruyter. New York, pp. 1337.

MADDISON, W. P., DONOGHUE, M. J. \& MADDISON, D. R., 1984, Outgroup analysis and parsimony. Syst. Zool., 33: 83-103.

MALLOCH, J. R., 1925, Notes on Australian Diptera. n. V. Proc. Linn. Soc. N. S. W., 50: 35-46. 
MALLOCH, J. R., 1928, Fauna sumatrensis (Beitra Nr. 56). Family Muscidae (Dipt.). Ent. Mitt., 17: 290-303, 310-336.

MATTHIS, W. N., 1977, Key to the Neotropical genera of Parydrinae, with a revision of the genus Eleleides Cresson (Diptera: Ephydrinae). Proc. Biol. Soc. Wash., 90: 553-565.

MATTHIS, W. N., 1978, A synopsis of the Neotropical Eleleides Cresson (Diptera: Ephydridae). Proc. Biol. Soc. Wash., 80: 465-472.

MICHELSEN, V., 1978, Cryptophyra lundbecki, n. gen. and n. sp. From North Europe, with some notes on hydrotaeine genera (Diptera, Muscidae). Entomol. Scand., 9: 85-92.

MICHELSEN, V., 1991, Revision of the aberrant New World genus Coenosopsia (Diptera, Anthomyiidae), with a discussion of anthomyiid relationships. Syst. Ent., 16: 85-105.

MORRONE, J. J. \& CRISCI, J. V., 1995, Historical biogeography: introduction to methods. Annu. Rev. Ecol. Syst., 26: 373-401.

NIXON, K., 1995, Clados, ver. 1.49. Program and documentation Trumansburg, New York.

PAMPLONA, D., 1999, Nova caracterização de Cyrtoneurina Giglio-Tos, 1983 e descrição de Paracyrtoneurina gen. n. (Diptera, Muscidae). Revta. Bras. Ent., 43: 9-24.

PAPAVERO, N., 1977, The world Oestridae (Diptera), mammals and continental drift. W. Junk, The Hague, 249p.

PONT, A. C., 1972, Family Muscidae. In: A catalogue of the Diptera of the Americas South of the United States. Museu de Zoologia, Universidade de São Paulo, São Paulo, v. 97, p. 111.

PONT, A. C., 1974, A revision of the genus Passeromyia Rodhain \& Villeneuve (Diptera, Muscidae). Bull. Brit. Mus. (Nat. Hist.), 30: 339-372.

PONT, A. C., 1980, Family Muscidae, pp. 721-761. In: R. W. Crosskey (ed.), Catalogue of the Diptera of afrotropical region, British Museum (Natural History), London, 1437p.

PONT, A. C., 1989, Family Muscidae, pp. 675-699. In: N. L. Evenhuis (ed.), Catalog of the Diptera of the australasian and oceanian regions. Special Publications of the Bernice Pauahi Bishop Museum, 1155p.
PONT, A. C. \& CARVALHO, C. J. B., 1997, Three new species of Muscidae (Diptera) from Dominician amber. Studia dipterologica, 4: 173-181.

PONT, A. C. \& PAMPLONA, D., 2000, A note on the genus Paracyrtoneurina Pamplona, 1999 (Diptera, Muscidae). Studia dipterologica, 7. Heft 1: 213-223

RAMOS, T. C., 1997, Tree Gardner 2.2. Privately distributed by Thiago Courrol Ramos, Museu de Zoologia, Universidade de São Paulo, Brasil.

SÉGUY, E., 1937, Diptera, family Muscidae. In: P. Wystmann (ed.), Genera Insectorum, Bruxelles, 205: 604

SKIDMORE, P., 1985, The biology of the Muscidae of the world. Junk, Dordrecht. Series entomologica, 29, xiv + 550p.

TEIXEIRA, D. M., 1999, Myiasis caused by obligatory parasites. Ib. General observations on the biology of the species of the genus Philornis Meinert, 1890 (Diptera, Muscidae). In J. H. Guimarães \& N. Papavero (eds.), Myiasis in man and animals in the neotropical region. Bibliographic database. Editora Pleaide, FAPESP, São Paulo, 308p.

TOWNSEND, C. H. T., 1935, Manual of myiology in twelve parts. Part II. Muscoid classification and habits. Charles Townsend \& Filhos, Itaquaquecetuba, Brazil, 296p., 9 pls.

TOWNSEND, C. H. T., 1937, Manual of Myiology in twelve parts. Part V. Muscoid generic diagnoses data, Glossinini to Agrinini. Charles Townsend \& Filhos, Itaquaquecetuba, Brazil, 234p.

VOCKEROTH, J. R., 1972, A review of the world genera of Mydaeinae, with a revision of the species of New Guinea and Oceania (Diptera:Muscidae). Pacific Insects, Monographies, 29: 1-134.

WATROUS, L. E. \& WHEELER, Q. D., 1981, The outgroup comparison method of character analysis. Syst. Zool., 30: $1-11$ 